\title{
Suitable for Children
}

\section{Ruth DYCK-FEHDERAU}

Ruth Dyck-Fehderau currently teaches at the University of Alberta in Edmonton. In her spare time, she writes stories and things, scores plays and things, lifts weights and things, and fantasizes about living in other lands.

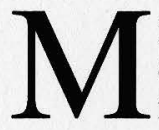

y mother has brought me a book from the church library again. She says she brings me books because my books from class aren't suitable for children. The book she brought me this time is called The Compleat Housewife. It doesn't have any pictures. Well, except for the picture on the cover. A tiredlooking woman from olden days sits by a thick table peeling vegetables with her red hands and a small knife. Stacks of vegetables sit beside her on the table and under it. I guess she'll be peeling for a long time. Maybe til her hands split and ooze out the cracks like

The Compleat Housewife: Or, Accomplish'd Gentle woman's Companion: $\mathrm{Pr}$ eface: It being grown as unfashionable for a Book now to appear to People without a Preface, as for a Lady to appear at a $\mathrm{Ba}$ ll without a Hoop-Pettico at; I shall conform to $\mathrm{Cu}$ stom for Fashion sake an

To make a Hare Pye, ski $n$ your hare, wash her, $d$ ry her, and bone her; sea son the flesh with pepper, salt, and spice, beaten fin in a stone mortar; do a $y$ beetjuice dripping from a knifecut. When I ask my mother why this book is for children if it doesn't have pictures, she says because it has Virtue. I ask her if books with Virtue can't have pictures, and she says I'd better just be quiet already and read it to her while she peels bushels and bushels of tomatoes for canning with her red hands and a small knife.

I show the book to my friend Darlene and we make the Salve For a Sprain. Except we don't know what burgundy pitch is and we don't have any frankincense so we use Vaseline and her mother's most expensive perfume instead. We pretend that Darlene 
oung pig at the same tim $e$ in the same manner; th en make your pye, and la $y$ a layer of pig and a la yer of hare till it is full; $p$

To make Salve For a Spr ain, Take a quarter of a $p$ ound of virgin-wax, a qu arter of a pound of franki ncense, half a pound of $B u$ rgundy pitch; melt them $w$ ell together, stirring them

expensive perfume. has a sprain in her bum and I have a sprain in my stomach. And I rub the sprain salve into her bum and she rubs it into my stomach until it's all gone and there isn't even any salve left to put in the little bottles in her doctor kit. Then Darlene says that smelling like expensive perfume might get us big spankings. So we sneak out to their cowbarn hayloft and play in the hay until suppertime so that we smell like cowbarn and hayloft and not too much like

One day, when I get home from school, my mother says not to read to her. My father killed a pig today. Behind the barn this afternoon, while I was in school, he pulled a knife across the pig's throat and opened the door to its hallways of blood. And then he hung it up by its back legs from a barn beam and let the blood fall out into a pail sitting on the barn floor. He took the saw that he uses to cut wood and the pig that was alive before and he sawed it in half the long way. Then he hauled it into the house, a half at a time, and heaved it up onto the kitchen table. Now he has taken the sharpest knife in the house, sharpened it some more, and is cutting the pig that was alive before into pieces the size of my mother's roasting pan. My mother says I have to go into the kitchen and keep him company.

I watch from the door. I want to be anywhere anywhere else in the world even the principal's office even the backroom closet where my father's new leather strap hangs beside the old leather strap he wore out. When

For a Distemper got by a $n$ ill Husband, Take two $p$ ennyworth of gum dragn ant, pick it and clean it, $a$ nd put it in an earthen pot ; put to it as much red ros $e$-water as it will drink up he reaches for the saw to pushpull it across an extra-thick bone, he sees me and asks me what I did at school today. The pushpulling jiggles the table. I watch a stopandgo stream of leftover blood wiggle to the end of a sawed-off pigfoot and somersault slowly into a red-brown puddle on the floor, and I think about the pig that was alive before, and I tell him that today I learned about people who are Vegetarians. 
He laughs. And gently, lovingly, slips the sharpest knife in the house under a thick warm strip of muscle and silently, smoothly slices it away from the bone. When the warm weight of it slides against his bare arm his fingers slowly move up to brush brush brush gently across it his eyes close halfway his cheeks and bald head turn pink his mouth opens halfway his upper lip gets shiny when his tongue drags slowly across it I've never seen him feel this good before.

So. I tell him I will read to him from the Bible. I walk into the kitchen, reach behind him and take the Bible down from the corner shelf beside his usual chair at the table.

drip drip

And moving into the farthest chair away from him, I open to Leviticus 11, and I read:

drrri

"The Lord said to Moses and Aaron, 'You must not eat the meat of a pig or touch its carcass. Whoever touches its carcass will be unclean. Do not defile yourself by any of these creatures. Do not make yourself unclean by means of them." And I drop the Bible and run away, knowing that he will not chase me with his bloody hands and drip red-brown blood through the house.

In the picture on the cover of The Compleat Housewife, a dead rabbit swings from the ceiling very close to the

To make a fine Hysteric Water, take zedoary, roo ts of lovage, seeds of wil $d$ parsneps, of each two ounces, roots of single pi ony four ounces, of mistl etoe of the oak three oun tired woman's head, its front paws almost brush brush brushing velvet across her forehead.

Her feet are hidden by a bunch of dead birds and a big dead red lobster. Oh, there's a puppy watching her. And it's alive. But it's not eating the dead birds on the floor. Puppies eat dead birds, you know. They do it all the time. Maybe this puppy knows that if it eats the dead birds, it will be next on the dead animal list and will be hung up by its back legs to swing 
from the ceiling and brush its fur across her forehead. Or maybe it knows it will get a very very big spanking too.

$* * *$

The next week, my mother brings me another book, even though I'm still reading The Compleat Housewife to her. It's called How to Tell Your Children About Sex: A Guidebook for Christian Parents. It doesn't have any pictures either. I'm supposed to read it alone, my mother says, but I show it to Darlene up in my bedroom the next Sunday afternoon. Quietly we read it to each other and try to understand. It tells us that when our children turn nine or ten or eleven, it's time to tell them about sex. And that what we should do is send our husbands away for the evening and let the girls come into the room when we change the diaper on their younger brother and show them his Genitals. Darlene asks if Genitals are like the Gentiles in the Bible. I tell her I don't think so, but we check the dictionary just to make sure.

The dictionary says that Genitals are human Gonads.

So. We look up Gonads. And there's a little picture. Genitals must be a boy's things. I know all about a girl's things, but I don't have a baby brother to look at so I've never even seen a boy's things. Darlene whispers that she hasn't either. So we put our heads under the blanket so no one can hear us whisper, and we decide to investigate Genitals and spy on our older brothers.

That night, I go to bed at 9:30, but I take The Compleat Housewife to bed with me and put it under my back to make sure I stay awake even when my eyes are closed. At 10:30, when I hear two of my brothers

A Plaister for Worms in Children: Take two oun ces of yellow wax, and a $s$ much rosin; boil them half an hour, stirring the $m$ all the while; skim th em well, and take it off and put to it three drac hms of aloes, and two $s$ come up the stairs and close their door, I climb out of my bed, pull up my nightgown so I don't trip on it, and tiptoe quickly down the green hallway carpet to their bedroom door. I can hear people moving around downstairs behind me and I know that if anyone sees me spying at this door I will get the worst spanking of my life. My bum still has sore places from 


\section{8 / Dyck-Fehderau}

the Leviticus spanking and our second batch of Salve For a Sprain isn't helping at all. Quietly quietly, I turn my brothers' door handle and push open the door the smallest, teeniest crack. I listen for footsteps on the stairs behind me, I crouch to make myself small, and, through the doorcrack, I watch.

My older younger brother climbs into bed and takes his clothes off under the sheets, throwing his pants and t-shirt out so they land on the floor. I can't even see his legs let alone his Genitals. And then he lays back and fastens his eyes on my older older brother undressing in front of him. My older older brother glances sideways at the door but he doesn't see that I have carefully opened it a tiny bit, I don't think he sees. His arms reach back to pull his t-shirt over his head and then down to push off his jeans. But when it comes time to take off his underwear, he turns slowly to face my older younger brother.

His back faces me and when the underwear

A Salve for the King's $E$ vil: Take a burdock-roo $t$ and a white lily-root, $w$ ash, dry and scrape them; wrap them in brown pap $e r$, and roast them in the embers; when they are so $f t$, take them out, and cut off the burn or hard, and slides down his legs onto the floor, all I see is his bum. An ordinary e ve ry d a y bum. Like Darlene's bum when I put Salve For a Sprain on it except bigger. And then he gets into bed and curls up slowly like a spoon close behind my older younger brother. Four nights in a row I spy on them and every night I see exactly the same thing. Just an ordinary everyday bum. Just an ordinary everyday bum. Finally, I give up on my brothers.

And decide I have to spy on my father. (This might not be such a good idea.)

He's the last one in the family to go to bed every night, so I have to stay awake longer. The first night, I fall asleep and wake up in the morning with a long bruise on my shoulder from where The Compleat Housewife dug into it. But the second time is better and I stay awake. After I hear him drag heavy feet up the stairs and into his bedroom, hear the door close behind him, I climb out of bed, pull up my nightgown so I don't trip on it, and tiptoe quickly down the green 
hallway carpet to his bedroom door. I try hard not to think about the new leather strap in the backroom closet as I quietly quietly turn the door handle and push the door open the smallest, teeniest crack. Listening for noises behind me, I crouch to make myself small, and, through the doorcrack, I watch.

He undresses slowly, slowly, like a tired old man. First, he unbuttons his denim shirt with his red sandpaper hands. When the shirt slides off his shoulders, he pulls in a sharp breath as it rubs over the scar from a long ago accident. Then come his jeans. He unzips, pushes them down to his knees, and he lands heavily on the bedside chair. Slowly, he bends forward to pull the jeans off the hook of his foot, a low growlsound falling from his mouth. And then all that's left is his underwear and socks, and I have a clear view of his front. But just as he's about to slide his underwear off he reaches inside the front of them straightens up turns to look at my mother asleep in the bed his eyes close halfway his cheeks and bald head turn pink his mouth opens halfway his upper lip gets shiny as his tongue drags slowly across it All of a sudden, I forget about the new leather strap and think of warm pigmeat, and I have to turn away quick quick, without seeing anything. I don't even make it to the stairs before bringing up and up and up.

One two three all the bedroom doors open just like that.

I am too sick even to feel guilty. When my brothers and my father complain about the smell of all the bringup, my mom tells them to go

A Cure to Stay Vomiting : Take ash-leaves, boil t hem in vinegar and wate $r$, and apply them hot to the stomach; do this ofte to bed, that I'm bringing up there on the green hallway carpet in front of her bedroom door because I was coming to wake her up and tell her I am sick and need something for my stomach. I'm so relieved that I bring up even more.

\section{$* * *$}

When I go back to school, Darlene meets me after school like always. As we walk home she tells me that she's not allowed to play with me anymore because my dad shot her dad's dog the last time he was in 


\section{0 / Dyck-Fehderau}

the mood. But she promises to send me secret notes about new doctor games I can play by myself. I give her a hug goodbye and when I do she whispers into my ear that she saw her brother's Genitals. She says the word like she owns it. Genitals. And she even saw him pee out of his thing. A straight thin stream like it poured out of the end of a straw, she says, like it poured out the end of a drinking straw.

****

All quotes are taken from Eliza Smith's The Compleat Housewife: or Accomplish'd Gentlewoman's Companion: Sixteenth Edition, With Additions. 1758. London: Studio Editions, 1994.

Thanks go to Workshop West Theatre and Guys in Disguise, especially to Ron Jenkins (director) and Daniela Vlaskalic and April Banigan (actors) who performed a version of this piece at Loud ' $N$ Queer 2001. Their input was invaluable. 